
University

\title{
Multifunctional agriculture and multifunctional landscapes - land use as an interface
}

Vejre, Henrik; Abildtrup, Jens; Andersen, Erling; Andersen, Peter Stubkjær; Brandt, Jesper; Busck, Anne; Dalgaard, Tommy; Hasler, Berit; Huusom, Henrik; Kristensen, Lone Søderquist; Kristensen, Søren Pilgaard; Præstholm, Søren

Published in:

Multifunctional Land Use

Publication date:

2007

Document Version

Early version, also known as pre-print

Citation for published version (APA):

Vejre, H., Abildtrup, J., Andersen, E., Andersen, P. S., Brandt, J., Busck, A., Dalgaard, T., Hasler, B., Huusom, H., Kristensen, L. S., Kristensen, S. P., \& Præstholm, S. (2007). Multifunctional agriculture and multifunctional landscapes - land use as an interface. In Ü. Mander, H. Wiggering, \& K. Helming (Eds.), Multifunctional Land Use (pp. 93-104). Springer.

\section{General rights}

Copyright and moral rights for the publications made accessible in the public portal are retained by the authors and/or other copyright owners and it is a condition of accessing publications that users recognise and abide by the legal requirements associated with these rights.

- Users may download and print one copy of any publication from the public portal for the purpose of private study or research.

- You may not further distribute the material or use it for any profit-making activity or commercial gain.

- You may freely distribute the URL identifying the publication in the public portal.

Take down policy

If you believe that this document breaches copyright please contact rucforsk@kb.dk providing details, and we will remove access to the work immediately and investigate your claim. 


\title{
Multifunctional agriculture and multifunctional landscapes - land use as an interface
}

\author{
Henrik Vejre ${ }^{1}$, Jens Abildtrup ${ }^{2}$, Erling Andersen ${ }^{1}$, Peter S. Andersen ${ }^{1}$, \\ Jesper Brandt ${ }^{3}$, Anne Busck ${ }^{4}$, Tommy Dalgaard ${ }^{5}$, Berit Hasler ${ }^{6}$, Henrik \\ Huusom $^{2}$, Lone S. Kristensen ${ }^{1}$, Søren P. Kristensen ${ }^{4}$, Søren Præstholm ${ }^{4}$ \\ 'Forest and Landscape, Royal Veterinary and Agricultural University, \\ Denmark \\ ${ }^{2}$ Food and Resource Economics Institute, Royal Veterinary and \\ Agricultural University, Denmark \\ ${ }^{3}$ Dept of Geography, Roskilde University, Denmark \\ ${ }^{4}$ Institute of Geography, Copenhagen University, Denmark \\ ${ }^{5}$ Danish Institute for Agricultural Sciences \\ ${ }^{6}$ National Environmental Research Institute, Denmark
}

\section{Introduction}

In contemporary sciences dealing with cultural landscapes, the concept of multifunctionality has gained increasing attention in the last decade. The scientific literature displays several attempts to frame the concept (e.g DeVries 2000; Anon 2001; de Groot et al. 2002) but there is much frustration regarding proper sets of broadly based definitions and clear statements concerning the authors' scientific points of departure (Anon 2001). Multifunctionality is on the one hand used to characterize the activities in the primary production sector, and the land use reflecting the material consequences of the various demands set by the society on land territories - these approaches relate to the agricultural understanding of multifunctionality. On the other hand, multifunctionality is used to characterize the landscape per se. The primary production sector (i.e. agriculture, forestry, horticulture and related land dependent activities) is considered having a primary or main function (production), and related joint productions, typically including a mix of material and non-tangible goods as well as a mix of private and public goods (externalities). Production of food and fibres is generally considered the primary products in this context, but the primary sector produces other material goods too, such as 
$\mathrm{CO}_{2}$ sequestration, groundwater recharge etc. Some of the by-products may be private goods, such as habitats for wild game for recreational hunting.

The landscape is regarded a physical spatial unit that may fulfil several purposes (possess several functions) for the society, and landscapes house per definition several spatial units that may fulfil different purposes (different functions) (Forman and Godron 1985).

Agriculture and landscapes share many characteristics. The actions of agriculture produce cultural landscapes, and landscapes are the theatre of agricultural activities. But notable differences between the two approaches to the concept of multifunctionality exist between agriculture and landscape. Much controversy arises solely because the scientific and management oriented viewpoints are quite different - the disciplines involved in multifunctionality of agriculture include agronomy, agricultural and environmental economics and sociology, whereas biology, geography, social sciences and humanities dominate in landscape sciences. From the agricultural viewpoint, the basic unit is the farm as an economic and social entity, from the landscape viewpoint the basic unit is the complex land system area analysed at different spatial levels.

If the differences between the two pathways were only abstract academic constructions, the world could probably live without having the concepts clarified, but in practical politics concerning agricultural policy, international trade and nature protection for instance, the aspects of multifunctionality are crucial concepts in the policy design of e.g UN, OECD, WTO, EU, and the FAO (Anon 1992; Anon 1996; DeVries 2000; Tait 2001; Rodriquez et al. 2004). Sound policy designs depend very much on mutual understanding between groups of interests. Clashes between interests are a common phenomenon, but clashes caused by different terminologies and terms of references are possible to avoid by careful analysis of terminology, concepts and viewpoints. There is in particular a need for clarification of the divergence and convergence of the concepts of function and multifunctionality in relation to agriculture and landscapes, respectively.

This need precipitated in 2003 the formation of a Danish network of scientists working with agriculture and landscape in a broad sense. The participating scientists represented sociology, agro-ecology, geography, biology, landscape ecology, agricultural and environmental economics and landscape architecture. In 2004 the network has performed its primary work in a series of workshop that sought to address the following issues:

1. The theoretical/philosophical concept of multifunctionality. Is it a new paradigm or can old concepts be applied and adapted in a constructive 
way? And how - if at all - does multifunctionality refer to sustainability?

2. Scientific viewpoint. Does the concept of multifunctionality give different meaning dependent on the viewpoint - political, management, scientific or farm unit? Can comprehensive models be developed?

3. Scale and perspective. The different points of departure with focus on $i$. The field or single ecotope, ii. The farm with its management logic, iii. The site or local level, $i v$. The landscape level, v. The regional level and $v i$. The market, related to the national and super national levels.

4. The concept of function. Which material and non - material functions can the concept of multifunctionality frame, both contemplated from a management viewpoint and a theoretical modelling viewpoint?

5. Indicators of functionality. Development of indicators and qualitative descriptors for agricultural functions and landscape functions including changes in functionality.

The multidisciplinary character of the network, and the open attitude among the participants soon revealed that the discussions on concepts, points of view and operational development were quite relevant for a scientific audience and for the management oriented sciences, and it was agreed that the thoughts and discussions of the group should be addressed in a number of scientific papers dealing with multifunctionality, and with groups of authors representing different sets of traditions and viewpoints. This chapter represents the general discussions and definitions of state-of the art, along with some visions for the scientific challenges for the next decade.

\section{The concept of multifunctionality - the agricultural path}

Multifunctionality in relation to agriculture has been an issue in the negotiations on international trade agreements, and has been treated in detail by the OECD (Anon. 2001). The definitions pertaining to the agricultural sector are related to economy or activity-oriented thinking. As OECD states; "Multifunctionality refers to the fact that an economic activity may have multiple outputs and, by virtue of this, may contribute to several societal objectives at once. (Multifunctionality is thus an activityoriented concept that refers to specific properties of the production process and its multiple processes)" (Anon. 2001). It should be noted that multifunctionality is not regarded a specific character of agriculture, but 
pertains to any economic activity. Key characteristics of multifunctionality relate to $i$. the existence of multiple commodity and non-commodity output that are jointly produced by agriculture, and ii. the fact that some of the non-commodity outputs exhibit the characteristics of externalities or public goods, with the result that markets for these goods do not exist or function poorly. Jointness in production can cover both "goods" and "bads" (e.g. Hasler et al. 2003).

The number of references to the OECD thinking proves this definition as a consensus-gathering one. There is a general agreement to consider the production function of agriculture the key function, referring to other functions as coupled, secondary, externalities, or services. (e.g. Bohman et al. 1999; Anon. 1999, 2003; Paarlberg et al. 2002; Peterson et al. 2002; Vatn 2002). The agricultural products, but also the production methods by which these products are achieved, are the reasons for the existence of the other functions (recreation, aesthetics, habitat etc.). This is why the aspects of multifunctionality attract both agricultural and environmental economists.

A short detour to the forestry sector reveals long traditions of multifunctional thinking, despite the terms used in forestry have included multiple-purpose or multiple-use forestry rather than multifunctional (Farrell et al. 2000). In the forestry sector the different functions have been weighted more evenly within the three dimensions economy (production of marketable goods), recreation and biology. The forestry sector has had long traditions of thinking in multiple uses, and there has been a clear consciousness as to the multifunctional status of the forests. As an example, the Danish forest legislation states clearly that the aim of forestry is to produce multiple goods and services, including traditional forest products, recreation and nature conservation (Anon. 2005).

There is a general consensus that multifunctionality is both a neutral characteristic of agriculture (joint production), but also that multifunctionality as a normative concept is useful in valuing outputs other than agricultural goods (landscapes, jobs, rural population, wildlife). On the other hand, multifunctionality is regarded as a bad excuse for the subsidy of agriculture in the "old world" (Potter and Burney 2002). Several industrialised countries claim that the externalities of agriculture should exempt them from changes in agricultural market subsidies, as the positive side-effects of multifunctional agricultural systems should be rewarded, whereas the elimination of subsidies will imply a loss of the benefits that agriculture provides, such as diverse ecosystems and cultural heritage amenities (Meyer 1999; Paarlberg et al. 2002; Romstad 2004).

The economic literature has also addressed the choice of appropriate instruments for regulation of multifunctional agriculture, i.e. what are the 
cost-effective instruments to ensure a social optimal mix of functions in agricultural landscapes (Abler 2004). The complexity of multifunctional landscapes and the multiple objectives of regulation of land use will normally demand a multiple mix of instruments to ensure a social optimal use of the landscapes. However, there will be a trade off between achieving the optimal use of the landscapes and the transaction costs of implementing regulations of agricultural production (Vatn et al. 2002). The transaction costs, e.g. the costs of designing, monitoring and enforcing the regulations, are often high due to the many linkages in the production processes, the diffuse nature of agricultural pollution, and the uncertainty from the variability of the climate and biological processes (Huusom 2005).

\section{The concept of multifunctionality - the landscape path}

The mere development of landscape sciences, not least under the broadly defined umbrella of landscape ecology, is an acknowledgement of the emergent properties of the earth surface as consisting of heterogeneous spatial units - landscapes. Landscape ecology as a science is rooted in the variation of landscapes. Landscape ecology deals with the reasons behind and consequences of variation in the landscapes. That is, structural heterogeneity and functional heterogeneity. Therefore, in essence, all landscapes are multifunctional per definition (e.g. Forman and Godron 1985), as one landscape will always be a conglomerate of different homogeneous units.

Multifunctionality attracts the attention of landscape scientists for many reasons, not least, the relationship between functionality, landscape structure and landscape diversity. In the 1990 'ies increased focus was put on the multifunctional character of landscape, not least because many environmental problems of the countryside were considered related to the segregation of functions and eradication of other functions than production from the land areas (Brandt and Vejre 2003). This strategy has resulted in monofunctional landscapes archetyped in areas of industrialised agriculture. Similar trends can be seen in forests and suburban dwellings and industrial and commercial zones.

During the era of the industrialisation of agricultural and silvicultural production, monofunctional land use was, in general, considered the most economically efficient land use development strategy.

However, the monofunctional use of landscapes often imply operations large land unit that hampers positive synergies between different potential 
functions within a landscape. Furthermore, monofunctional land use does not reflect the multifaceted character of the human demands.

The actors within the landscape sciences have not reached a common agreement on the terms function and hence multifunctionality. Despite the common understanding on the landscape as functional units, the literature on landscape ecology is poor in precise definitions on landscape function. Leser (1995) refers to a functional principle, which he considers difficult to realise due to "the character of functionally super complex landscape ecosystems". Forman and Godron (1986) define function as "the interactions among the spatial elements, that is, the flows of energy, materials, and species among the component ecosystems". Accordingly, in most landscape ecology literature, landscape functions are often described as being synonymous with landscape processes (e.g. Zonneveld 1995), without further detailing.

Table 1. Some basic differing characteristics between multifunctionality in agricultural and landscape context respectively.

\begin{tabular}{|c|c|c|}
\hline Variable & Agriculture & Landscape \\
\hline Basic statement & $\begin{array}{l}\text { All production have } \\
\text { linked products, } \\
\text { externalities" }\end{array}$ & $\begin{array}{l}\text { All Landscapes are } \\
\text { multifunctional, per } \\
\text { definition" }\end{array}$ \\
\hline Base unit for analysis & Farm as base unit & Land system as base unit \\
\hline Basic characteristic & Activity-oriented & Emergent feature \\
\hline Rating of functions & $\begin{array}{l}\text { Agricultures primary } \\
\text { function is production, } \\
\text { Welfare economic criteria }\end{array}$ & $\begin{array}{l}\text { All functions are rated equal, } \\
\text { dependent on the point of } \\
\text { departure }\end{array}$ \\
\hline $\begin{array}{l}\text { Concept used in } \\
\text { relation to }\end{array}$ & $\begin{array}{l}\text { Optimisation of land use, } \\
\text { Policy design, e.g. } \\
\text { subvention schemes, } \\
\text { valuation of externalities, }\end{array}$ & $\begin{array}{l}\text { Environmental regulation, } \\
\text { problems caused by } \\
\text { segregation of functions }\end{array}$ \\
\hline Disciplines involved & $\begin{array}{l}\text { Agronomy, agriculture } \\
\text { economy and sociology }\end{array}$ & $\begin{array}{l}\text { Biology, geography, social } \\
\text { sciences and humanities }\end{array}$ \\
\hline Definitions & $\begin{array}{l}\text { Relatively well defined } \\
\text { and accepted }\end{array}$ & $\begin{array}{l}\text { Blurred definitions, no general } \\
\text { accepted terms }\end{array}$ \\
\hline
\end{tabular}

There are several approaches to the terms - some rooted in production, some more broadly based encompassing production and services as habitat, water supply etc (de Groot 2002) and attempts of establishing a taxonomy for landscape functions (e.g. Brandt and Vejre 2004; Wytrzens and Pistrich 2003). In contrast to the agricultural entry, where functions may be divided in a primary and secondary functions (production and externalities), functions of landscapes are not by definition grouped in 
primary and secondary functions, rather the functions in focus are dependent on the point of departure of the observer. Table 1 displays some of the differences between the landscape path and the agricultural path.

\section{The common denominator - land use}

Though the concept of multifunctionality in relation to agriculture and landscapes has quite different origins the two approaches obviously share much in common, and multifunctionality in relation to the two are sometimes used arbitrarily. One of the prime joint products or externalities of agriculture is open landscapes, and in cultural landscapes, agricultural production is often a major function. Figure 1 displays an attempt to conceptualize the relation between the two entries. Agriculture is represented by the farm as a system, or network, a unity with several relations to the surroundings, i.e. the society, physical environment etc. The relations are expresses as functions fulfilled by the farm. The farm's primary function is the production - and the area-related production is denoted land use. The landscape is represented by a complex landscape system, with the many functions related to the services to human societies offered by the landscape. In the landscape system, the production function, which typically is indicated by land use, is one of several functions.

Both systems employ land use as a base characteristic, and land use is hence a common denominator that may bridge the two entries to multifunctionality. The overlap between the farm system and the rural landscape system is represented by the crescent denoted land use.

The fact that land use is employed by both the agricultural and landscape pathways is supported by the many definitions on land use that are available today. These definitions represent also a landscape or land entry: the presence of natural processes and productivity or human-made forms of productivity (e.g. agriculture, forestry, or mining) or use (e.g. recreation, residential, commercial, or industrial) on a parcel of land (www.mde.state.md.us/Programs/WaterPrograms/Wetlands_Waterways/a bout_wetlands/glossary.asp), and an agricultural/activity entry: how people use the Earth's surface (e.g., urban, rural, agricultural, range, forest); often subdivided into specific uses (e.g., retail, low-density housing, industrial).

www.nmlites.org/standards/socialstudies/glossary.html or: the way in which land is used, especially in farming and city planning www.nrdc.org/reference/glossary/l.asp. 


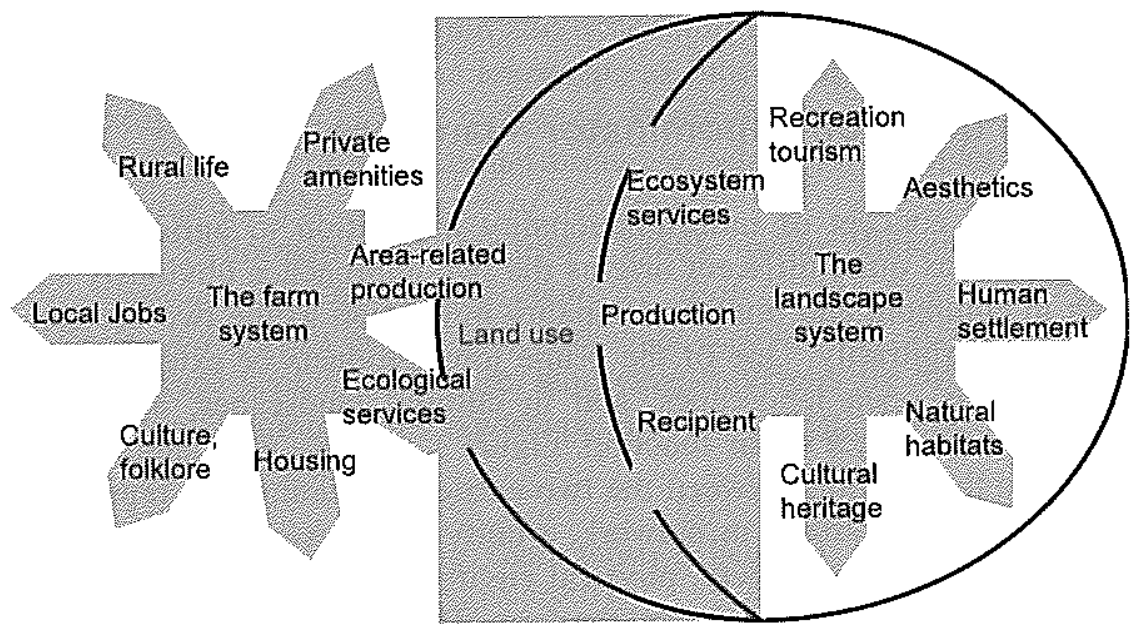

Figure 1. The overlap between the farm system and landscape system of a rural landscape. Both systems are multifunctional, here displayed with a selection of different functions pointing in all directions. The farms primary function is the production - and the area-related production is denoted land use. In the landscape system, the production functions is one of several functions. The production function is indicated by land use. Both systems employ land use as a base characteristic. Land use is hence a common denominator that may bridge the two entries to multifunctionality. (Inspired by Noe, 2005, unpublished model).

It should be noted that land use mapping differs from land cover mapping in that it is not always obvious what the land use is from visual inspection.

Land use is from both the agricultural viewpoint and the landscape viewpoint a term that makes much sense in describing the functionality of the system. In the literature, reference to multifunctional land use may be found too, thereby representing integration of production functions, for instance in the commonly used terminology spatial integrated land use, temporal integrated land use, and spatially/temporal integrated land use (Brandt and Vejre 2004). 


\section{The common operator - management of agricultural landscapes}

The significance of both multifunctional agriculture and landscapes is strongly related to the management of both. In the post modern world, there is much focus on the externalities of agriculture, and an incentive for farmers to participate in other activities than production (e.g agri-environmental measures, farm tourism etc.), and in densely populated countries or regions, there is an urgent need to combine different functions on the same territorial units - both at the landscape and at the site level. Combing functions imply typically integration of production, habitat, recreation and ecosystem services. That is, management for multifunctional land use in multifunctional landscapes.

In order to target the management specifically, the concepts of territorial, spatial and functional competences may be useful (Hägerstrand 1995). The territorial competence exerted by the single landowner is significant when addressing management that may be dealt with most efficient by the individual. However, in scales encompassing more than one landowner, the authorities must exert spatial competence through legislation, plans or subvention. The introduction of new ideas and visions for the landscape in casu multifunctionality - will in practical management meet a world in which there is much resistance against rapid change.

\section{Outlook - challenges for further research}

The transdisciplinary forum of the Danish network has had thorough discussions regarding the crucial questions to be dealt with in the future scientific research on multifunctional landscapes, land use and agriculture. The network decided to put focus on the following themes:

1. Taxonomy and classification. Despite some attempts to list landscape functions and group them into classes, all experience tell us that these schemes are subject to fierce discussion. Taxonomies and definitions should include scientists from all branches - social sciences, humanities and natural sciences, including the production oriented; as landscapes are holistic complex systems the different viewpoints must be included in a taxonomy to be operative. A solution on the taxonomy problem would enable us to move forward towards solving the below mentioned problems.

2. Quantification, characterisation and mapping. There are long traditions of mapping and quantification, or at least semi - quantification, of land- 
scape functions - e.g. land uses classes, crop yield etc. But several functions we have certainly refrained from quantifying - and certainly not mapped. There is a need for developing sound indicators and spatially related descriptors for all types of functions. The indicators must be scalable, and specifically adaptable to spatial heterogeneity, often of a fuzzy character, and ultimatively lead to exact spatial locations. Preferably with exact spatial extent of functions. Because of the structural and functional heterogeneity of landscapes, some functions has distinct relations to specific compartments of the territory, while other functions more has a network character, with more diffuse relations to geographical locations in other landscapes around the Globe.

3. Operational approach to landscape functionality. In order to operationalize our knowledge of the multifunctional character of landscapes, the knowledge needs to be embedded in tools to manage multifunctionality. This includes tools at the societal level (planning, policy design etc.) as well as at the farm level (advisory tools, farm management, planning tools etc.)

4. Policy analysis approaches to multifunctionality. Multifunctionality is used as a political argument for subsidies to the agricultural sector, to promote specific land uses and production methods for environmental reasons as well as objectives regarding development of rural areas. There is further need to analyse and assess both costs and benefits of these aspects of multifunctionality compared to other regulatory and policy approaches. The costs and benefits should be analysed and assessed both for the sectors involved and for the society's welfare. In addition, there is a need to analyse how, when and why multifunctionality is included into legislation and public planning.

5. Sustainability and multifunctionality. The links between sustainability and multifunctionality must be established - if they exist. This deals with the need to decide whether multifunctionality is a neutral term or a normative concept. There is a need for concrete analysis of real landscapes - development of functions, multifunctionality and the degree of sustainability.

\section{References}

Abler D (2004) Multifunctionality, Agricultural Policy, and Environmental Policy. Agricultural and Resource Economics Review 33: 8-17.

Anon. (1992) Rio Earth Summit - Agenda 21. UN Dept of Economic and Social

Affairs, Division for Sustainable Development, New York.

Anon. (1996) Rome Declaration on World Food Security, FAO. Rome Italy. 
Anon. (1999) The European Commission: Info-Paper, October 1999, Bruxelles. Anon. (2001) Multifunctionality. Towards an analytical Framework. OECD Publications. Paris.

Anon. (2005) Danish Forest Act .

http:/www.skovognatur.dk/NR/rdonlyres/9D92132E-C3A3-4EA2-AA7C-

CA099FA9B765/5784/Forestact.pdf

Bohman M, Cooper J, Mullarkey D, Normile MA, Skully D, Vogel S, Young E (1999) The use and abuse of multifunctionality. USDA/Economic Research Service, Washington DC.

Brandt J, Vejre H (2004) Multifunctional Landscapes, Motives, concepts and perspectives. In: Brandt J., Vejre H. (eds) Multifunctional Landscapes. Vol 1 and 2. Advances in Ecological Sciences. Wit Press, Southampton.

DeVries B (2000) Multifunctional Agriculture in the International Context: A Review. The Land Stewardship Project

Farell EP, Fuhrer E, Ryan D, Anderson F, Huettl R, Piussi P (2000) European forest ecosystems: building the future on the legacy of the past. Forest Ecol. Manag. 132: 5-20.

Forman RTT, Godron M (1985) Landscape Ecology. J. Wiley and Sons.

de Groot RS, Wilson M, Boumans RMJ (2002) A typology for the classification, description and valuation of ecosystem functions, goods and services. Ecological Economics 41: 393-408.

Hasler B, Romstad E, Schou JS (2003) The complexity of modelling farmers' provision of landscape goods in a multifunctional setting. In: Brandt J, Vejre $\mathrm{H}$ (eds) Multifunctional landscapes - monitoring, diversity and management. Advances in Ecological Sciences Volume 15. WIT Press, Southampton.

Hägerstrand $T$ (1995) A look at the political geography of environmental management. In: Landscape and Life: Appropriate scales for sustainable development. LLASS Working Paper No 17. University College Dublin.

Huusom H. (2005) Transaktionsomkostningsteori og styringsmidler i miljøreguleringen af landbrug. Samfundsøkonomen 2: 20-23.

Leser H (1991) Landschaftökologie. Verlag Eugen Ulmer, Stuttgart.

Meyer H v (1999) Nature and Farming in a European Perspective. Temarapport 1. Natur og Landbrug. Copenhagen, Naturrådet.

Paarlberg PL, Bredahl M, Lee JG (2002) Multifunctionality and Agricultural Trade Negotiations. Review of Agricultural Economics 24: 322-35.

Peterson JM, Boisvert RN, De Gorter H (2002) Environmental policies for a multifunctional agricultural sector in open economies. European Review of Agricultural Economics 29: 423-43.

Potter C, Burney J (2002) Agricultural Multifunctionality in the WTO-legitimate non-trade concern or disguised protectionism? Journal of Rural Studies 18: 35-47.

Rodrigues MR, Gómez EG, Lorente JC (2004) Rural multifunctionality in Europe. The concept and policies. 90 $0^{\text {th }}$ EAAE Seminar "Multifunctional agriculture, policies and markets: Understanding the critical Linkage. Rennes, France. 
Romstad E (2004) Multifunctionality - focus and resource allocation. Plenary paper 90th EAAE Seminar Multifunctional agriculture, policies and markets: understanding the critical linkage. October 28-29, 2004, Rennes.

Tait J (2001) Science, Governance and Multifunctionality of European Agriculture. Outlook on Agriculture 30: 91-95.

Vatn A (2002) Multifunctional Agriculture: some consequences for international trade regimes. European Review of Agricultural Economics 29: 309-327

Vatn A, Kvakkestad V, Rørstad PK (2002) Policies for multifunctional agriculture: The trade-off between transaction Costs and Precision. Agricultural University of Norway, Department of Economics and Social Sciences. Report no. 23.

Wytrzens HK, Pistich K (2003) Measuring the multifunctionality of mountaineous grassland in Austria. In: Brandt J, Vejre $\mathrm{H}$ (eds) Multifunctional Landscapes. Vol II WIT Press Southampton.

Zonneveld I (1995) Land Ecology. SPB Academic Publishing, Amsterdam. 